\title{
Recovery in soil cover and vegetation structure after ancient landslide in mountain fens under Caltho-Alnetum community and response of soil microarthropods (Hexapoda: Collembola) to natural restoration process
}

\author{
Paweł Nicia ${ }^{1}$ (D) $\cdot$ Romualda Bejger $^{2} \cdot$ Maria Sterzyńska $^{3} \cdot$ Paweł Zadrożny $^{1} \cdot$ Piotr Parzych $^{4} \cdot$ Agnieszka Bieda $^{4}$. \\ Anita Kwartnik-Pruc ${ }^{4}$
}

Received: 12 March 2019 / Accepted: 11 August 2019 / Published online: 31 August 2019

(C) The Author(s) 2019

\begin{abstract}
Purpose The objective of this study was to determine the long-term environmental changes induced by ancient landslide in the mountain fen. Attempts were made to demonstrate the progress of the soil cover restoration process about 200 years after the landslides and associated with changes in vegetation and soil microarthropod biodiversity and occurrence pattern associated with the restoration of soil cover.

Material and methods The study covered mountain fen of the Caltho-Alnetum in the Babiogórski National Park in Outer Flysch Carpathians, Poland, where ancient landslide deposits are causing disturbance in fen hydrologic regime and over time related to various rate of fen area natural restoration processes. The drill test has been used to assess changes in layering and thickness of the fen soils. The following soil parameters, such as $\mathrm{pH}$ and total organic carbon content, were determined at each distinguish layer. The diversity and distribution pattern of soil microarthropods, represented by Collembola, was examined in two parts of the fen: restored and not-restored. The soil parameters, such as $\mathrm{pH}$, electrical conductivity, total exchangeable base, total organic carbon, and nitrogen content, were determined in the soil samples simultaneously. The assessment of the vegetation structure recovery within studied mountain fen after landslide was referred to average parameters of the community completed for other natural mountain fens under the Caltho-Alnetum community. The research results were statistically verified.

Results and discussion The test drillings showed that landslides change soil layering, site-specific soil properties of mountain fen such as chemistry (the statistically significant differences were noted only in the case of total organic carbon content), vegetation structure, and soil microarthropod communities. By changing site-specific conditions, landslides influence on the biodiversity and peatland ecosystems functioning.

Conclusion Our results clearly demonstrate that the landslide itself initiated a complex and lengthy process of changes in biological aspects of peatlands including the biodiversity of the underground fauna and plant community. Soil microarthropod communities represented by Collembola can be used as a good indicator of mountain fen restoration process.
\end{abstract}

Keywords Mass movements $\cdot$ Mountain peatlands $\cdot$ Springtails $\cdot$ Vegetation

Responsible editor: Jean Louis Morel

Electronic supplementary material The online version of this article (https://doi.org/10.1007/s11368-019-02434-z) contains supplementary material, which is available to authorized users.

\section{Paweł Nicia}

rrnicia@cyf-kr.edu.pl

1 Department of Soil Science and Soil Protection, University of Agriculture in Kraków, al. Mickiewicza 21, 31-120 Kraków, Poland
2 Department of Physics and Agrophysics, West Pomeranian University of Technology in Szczecin, ul. Papieża Jana Pawła IV/3, 71-459 Szczecin, Poland

3 Museum and Institute of Zoology PAS, Wilcza 64, 00-679 Warsaw, Poland

4 Faculty of Mining Surveying and Environmental Engineering, AGH University of Science and Technology, Kraków, Poland 


\section{Introduction}

According to the European Union Strategy for Soil Protection (COM232/2006), landslides are one of the main eight threats to European soils, especially in mountainous and hilly regions (Lacasse and Nadim 2009). As natural disturbance factors (geological structure, topography, rainfall) or stimulated by human activity, they may raise the geo- and biodiversity of an area (Geertsma et al. 2009; Pop and Chitu 2013; Pánek and Lenart 2016). The mass movements are simultaneously material redistribution and erosion processes, which create a complex microtopography, on the one hand, with very dry ridges and hummocks, on the other, sometimes with small areas of standing water in depressions (Pop and Chitu 2013). In mountainous areas, the most common factor contributing to landslides and intensive erosion is deforestation and land-use change (García-Ruiz et al. 2017). Deforestation, which has a negative impact on the capacity of soil to retain water, may intensify soil erosion and increase the risk of flood (ReinhardtImjela et al. 2018).

The landslide problem in the Polish Carpathians was presented by Poprawa and Ryczkowski (2003), Alexandrowicz and Margielewski (2010), and Błońska et al. (2016). On the basis of research carried out in 2008-2010 (Polish Landslide Protection System), about 50-60 thousand landslides were identified and recorded in the Carpathians, which constitutes 95\% of all registered in Poland. In the most susceptible regions of those mountains, about $30-40 \%$ of the area is covered by landslides or other forms of mass movements. It was calculated that for every square kilometer of an area, there is an average of one landslide in this region of Poland (Kogut et al. 2018).

In mountain fen under Caltho-Alnetum community, with perennially saturated soils but without obvious surface flooding, the mass movement effect and recovery over time have never been studied. The fens of the Outer Flysch Carpathians are interflow-fed forest areas, where groundwater including solutes from the whole catchment seeps out. They develop on slope horizons, where alluvial groundwater supports peat formation and in places where underground waters come to the surface. In the Polish Flysch Carpathians, they are classified among the peat-forming wetlands (Gnatowski et al. 2010) as soligenous fens (Nicia 2009) or they can be classified as slope fens (Charman 2002). The main threat of those forested mountain fens is groundwater alteration, by drainage for forestry (Harrison et al. 2010), which can provoke responses of soil biota to hydrologic regime changes (Sterzyńska et al. 2015).

The mass movements can induce the long-term environmental changes and control developmental process of peatlands. They can also affect the biotic recovery and contribute to the soil fauna diversity change, including soil microarthropods. Collembola are one of the most abundant groups within soil microarthropods. They play an important role in soil formation, transformation and decomposition of soil organic matter, distribution of soil particles, water infiltration rate, nutrient cycling, mineralization, immobilization, availability of $\mathrm{N}$ and other nutrients, and the composition, abundance, and dispersal and activity of bacteria and mycorrhizal fungi (Brussard 1997; Rusek 1998; Menta 2012; Briones 2014). Collembola could quickly respond to habitat disturbances, such as a seasonal drought, air warming (Xu et al. 2012), changes in hydrologic regime in a river floodplain (Sterzyńska et al. 2014), and the restoration of drainage ditches and water diversions in mountain fens (Nicia et al. 2018a, b). The studies on the soil microarthropods recovery, represented by Collembola communities, and the ancient landslide disturbance within the mountain fen have never been considered.

The objective of this study was to determine long-term environmental changes induced by ancient landslide in the mountain fen properties under the Caltho-Alnetum community. Attempts were made to demonstrate the progress of the soil cover restoration process about 200 years after the landslides, vegetation structure recovery, and soil microarthropod biodiversity and occurrence pattern associated with the restoration of soil cover.

\section{Materials and methods}

\subsection{Setting}

The mountain fens under the Caltho-Alnetum community in the Babiogórski National Park in Outer Flysch Carpathians are priority biotopes listed in the annex to the 1st EU Habitats Directive (Council Directive 92/43/EEC 1992). They represent a soligenous type of hydrological feeding, where water feeding came from aquifers. In 1960s and 1970 s, the majority of mountain fens under the CalthoAlnetum community in the Babiogórski National Park were drained (Nicia et al. 2018b). However, the anthropogenic impact on the fens started much earlier, i.e., around 1835, when people who settled in those areas started developing agriculture on land previously occupied by forests (Nakadai 2006).

\subsection{Study area}

The study covered an ancient landslide area of the mountain fen under Caltho-Alnetum community in the Babiogórski National Park (Fig. 1) in Outer Flysch Carpathians, Poland $\left(49^{\circ} 36^{\prime} 43^{\prime \prime} \mathrm{N}\right.$ and $\left.19^{\circ} 30^{\prime} 57^{\prime \prime} \mathrm{E}\right)$, situated at the level of the lower montane zone on the slope from $1^{\circ}$ to $8^{\circ}$. The habitat area was about 0.15 ha. The characteristic for Caltho-Alnetum association plant species, such as Caltha paluistris, Valeriana simplicifolia, Agropyron caninus, and Alnus incana, appeared only at the fen part, where the transition of groundwater 
Fig. 1 Map location of studied mountain fen under CalthoAlnetum community

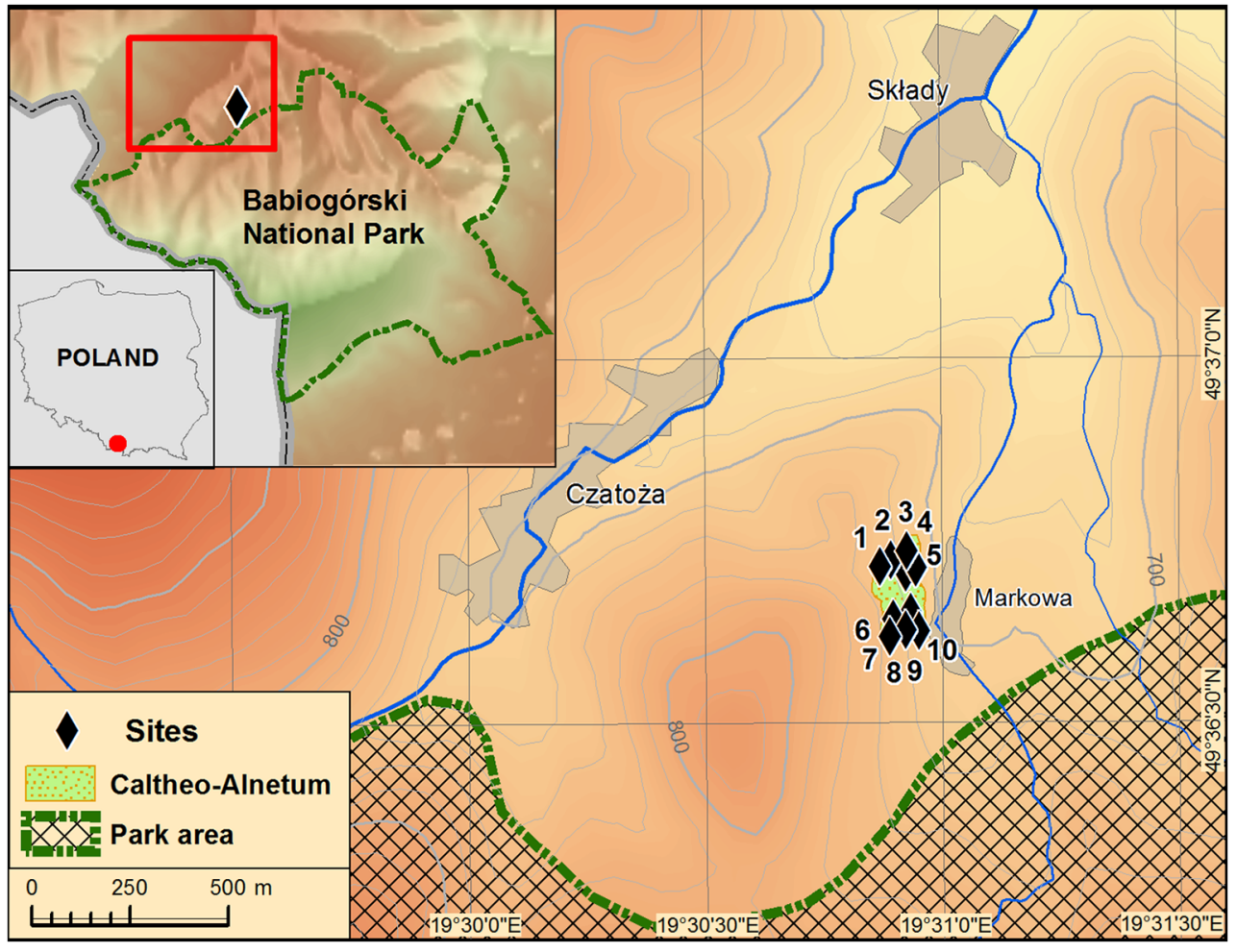

through the soil profile was restored over 200 years after landslide. The Dentario glandulosae-Fagetum association gradually dominated at the drier fen part, where water conditions were not restored.

\subsection{Soil sampling and analysis}

The cross-section through fen was done in 2015 to determine changes in soil layering and thickness. Altogether 103 wells in 8 transects were drilled (the distances between the wells in transects were $2.5 \mathrm{~m}$, and the distances between individual transects were $10 \mathrm{~m}$ ).

The soil chemical characteristics, such as $\mathrm{pH}$ and total organic carbon (TC), were measured in separate soil samples taken from each distinguished layer. Furthermore, the soil chemical characteristics, such as $\mathrm{pH}$, electrical conductivity (EC), total exchangeable base cations (TEB), total soil organic carbon, and total nitrogen (TN), were measured in the three soil samples collected from the first (organic) layer of restored and not-restored part of fen at each chosen for soil microarthropod research plot.

Before chemical analysis, soil samples were air dried and crushed. The soil $\mathrm{pH}$ was measured in a 1:2.5 $(w / v)$ soil:water suspension and $1 \mathrm{~mol} \mathrm{dm}^{-3} \mathrm{KCl}$ solution, using the potentiometric method (Tan 2005); electrical conductivity (EC) was determined in a fresh soil: water suspension according to Dojlido (1999); total exchangeable base (TEB) cation concentration was calculated as TEB $=\left(\mathrm{Ca}^{2+}\right)+\left(\mathrm{Mg}^{2+}\right)+\left(\mathrm{K}^{+}\right)+$
$\left(\mathrm{Na}^{+}\right)$; the base cation $\left(\mathrm{Ca}^{2+}, \mathrm{Mg}^{2+}, \mathrm{K}^{+}\right.$, and $\left.\mathrm{Na}^{+}\right)$concentration, after extraction with $1 \mathrm{~mol} \mathrm{~L}^{-1} \mathrm{CH}_{3} \mathrm{COOHN}_{4}$ solution (Tan 2005) individual cations were determined by atomic emission spectrometry with inductively coupled plasma (ICP-OES) using Perkin Elmer Optima 7300DV optical emission spectrometer (plasma gas-flow was $15 \mathrm{dm}^{3} \mathrm{~min}^{-1}$, external gas flow $-0.2 \mathrm{dm}^{3} \mathrm{~min}^{-1}$, nebulizing gas flow $0.6 \mathrm{dm}^{3} \mathrm{~min}^{-1}$; calibration was carried out using certified reference material ERM ${ }^{\circledR}-\mathrm{CD} 281$ ); total organic carbon (TC) and total nitrogen (TN) content was estimated using LECO CNS 2000 automatic analyzer (LECO 1996).

\subsection{Sampling of soil microarthropods}

The 10 research plots were selected for evaluation of diversity and distribution pattern of soil microarthropods, represented by Collembola: five (1-5) within in a restored part and five (6-10) within in a not-restored part of fen. The three random litter + soil cores were taken from each plot with a steel core (diam. $5.5 \mathrm{~cm}$ to $15 \mathrm{~cm}$ depth). Collembola from soil and litter layers were extracted in a modified MacFadyen high-gradient apparatus (Macfadyen 1961) for a maximum of 10 days. Collembola were identified to the species level according to the recent specified synopses and identification keys (Fjellberg 1998, 2007; Pomorski 1998; Bretfeld 1999; Potapov 2001; Thibaud et al. 2004; Dunger and Schlitt 2011; Jordana 2012). All specimens are deposited at the Museum and Institute of Zoology PAS (Warsaw, Poland). 


\subsection{Sampling of vegetation}

The phytosociological relevés were taken in 2015 in the studied mountain fen. Due to the lack of data in vegetation flora composition before ancient landslide deposits, assessment of the vegetation structure recovery was referred to average parameters of the plant community completed for other natural forested mountain fens under Caltho-Alnetum community by Celiński and Wojterski in the 1970s (Celiński and Wojterski 1978). The 23 of the previous phytosociological relevés were used as a source of information of vegetation recovery.

\subsection{Statistical analysis}

To assess differences in chemical soil parameters (pH and total organic carbon content) between the three layers, the one-way ANOVA was used. Prior to the analysis, the chemical soil data for normal distribution (Shapiro-Wilk test) and homogeneity of variances (Levene's test) were checked. Tukey's HSD test was used to determine significance of differences.

The two-tailed nonparametric Mann-Whitney $U$ test was used to assess the differences in Collembola community structure parameters, such as abundance ( $A$, expressed as number of individuals per square meter), species richness $(S)$, Shannon's diversity index $\left(H^{\prime}\right)$, and Pielou evenness $\left(J^{\prime}\right)$ (Magurran 2004) between "restored" and "not-restored" part of the mountain fen. The multivariate analysis was used to evaluate the relationship between the Collembola community composition and environmental variables. Because, in this particular case, the gradient length calculated for the first axis of DCA was longer than 3.0 $\mathrm{SD}$, we used the canonical correspondence analysis (CCA) (see Leps and Smilauer 2003). To assess the relative importance of landslide disturbance on the Collembola community variation, we calculated CCA constrained by soil $\mathrm{pH}$, electrical conductivity (EC), total organic carbon (TC), and total nitrogen (TN) content as well as total exchangeable base (TEB). Only relevant environmental variables with a low inflation factor were used in the CCA model. Variables demonstrating a high variance inflation factor (VIF > 20), indicating a high multicollinearity between predictors and the lack of unique contribution to the regression equation, were removed from the final analysis. The interactive stepwise (forward) selection for statistical model selection of environmental variables was used to assess the potential value of each individual environmental variable separately (simple effect) and the partial (conditional effect) on predictions of the model explaining the highest amount of variation in studied collembolan communities. We performed the analysis using a data matrix in which the values in a cell were means obtained for each research plot from taken separately three soil cores for soil properties and simultaneously three soil cores for species abundances. We performed the analysis using a data matrix in which the values in a cell were means obtained for each research plot from taken separately three soil cores for soil properties and for species abundances. Before the calculation of ordination model, species data were standardized to one square meter and then $\log (x+1)$ transformed. Plots were treated as replicates in the analysis. The significance of the model was estimated by means of the Monte Carlo permutation test with 499 randomizations. Significance level was $P \leq 0.05$ for all analyses. Calculations were made using Statistica 12.0 and Canoco 5.0 software packages.

\section{Results}

The test drillings showed that mountain fen soils are composed of the three layers: $\mathrm{I}$ - organic layer with a thickness of 0.1 to $0.3 \mathrm{~m}$; II — deluvial deposits formed by landslide with a thickness from several centimeters on the fen edge to over $0.5 \mathrm{~m}$ in its central part; and III - original peat layer formed before mass movements with a thickness from several centimeters on the fen edge to over $0.8 \mathrm{~m}$ in its central part (Fig. 2). The volume of the original, organic material resulting from the peat-forming processes before landslides was about $184.5 \mathrm{~m}^{3}$. The soils of this layer were characterized by the statistically significant highest total organic carbon content in comparison with the first and
Fig. 2 Cross-section through soils of habitat (I- organic layer; II-mineral (deluvial) layer; IIIoriginal layer)

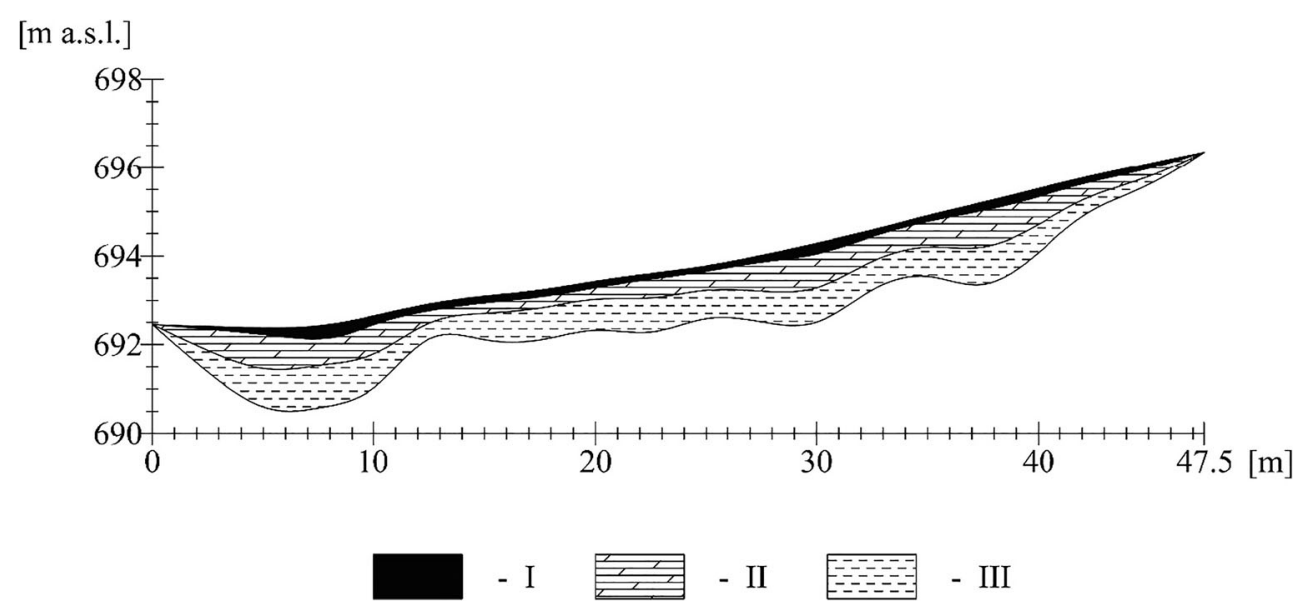

[m a.s.1.] 
second layer (Table 1). The second layer volume with the mineral material was about $389 \mathrm{~m}^{3}$. The soils of this layer were characterized by about the six times lower the total organic carbon content in comparison with the original layer. The first layer was characterized by the new organic layer with the volume about $223 \mathrm{~m}^{3}$. The $\mathrm{pH}$ values, among distinguished three soil layers, were not significantly different; nevertheless, the highest $\mathrm{pH}$ values were recorded in the deepest, original layer. The layers situated above the groundwater level showed lower $\mathrm{pH}$ (Table 1).

Analysis of changes in the structure of the plant community through the comparison with the Caltho-Alnetum reference areas showed that recovery of the plant community typical for the mountain fens, within 200 years after the appearance of the landslide, have not been completed. There are still significant discrepancies in the percentage coverage through tree canopy, shrubs, or moss layer (Table 2). Tree species, especially Acer pseudoplatanus, Alnus incana, Fraxinus excelsior, Picea excelsa, Picea abies, Sorbus aucuparia, Picea excelsa, and Picea abies as well as in the ground cover and the expansion of nitrophilous species, such as Rubus idaeus, Rubus hirtus, and Urtica dioica, were observed.

A total of 1016 individuals representing 24 Collembola species were identified within the mountain fen influenced by the landslide (Fig. 3 and Appendix A, B in the Electronic Supplementary Material). The mean values of Collembola abundance $(A)$ and species richness $(S)$ were significantly lower in the restored part of the fen, while diversity indices, such as Pielou evenness index $\left(J^{\prime}\right)$ and Shannon diversity index $\left(H^{\prime}\right)$, increased (Table 3). The total variation explained by CCA model that included the soil chemical predictors, such as $\mathrm{pH}$, electrical conductivity (EC), nutrient content (total organic carbon and nitrogen), and total exchange bases (TEB), accounts for $68.1 \%$ (adj. $28.1 \%$ ) of the Collembola variation within fen (lambda trace $1.466, F=1.7, p=0.008$ ). Total organic carbon content was the best predictor of the Collembola communities' variation ranked by the interactive stepwise (forward) selection method and significantly contributed to the CCA model (conditional effect) (Table 4). Sminthurinus aquaticus and S. malmgreni were

Table 1 The physicochemical properties of the layers across mountain fen $(n=103)$

\begin{tabular}{lllll}
\hline Layers & Volume & $\mathrm{TC}$ & $\mathrm{pH}$ & \\
\cline { 3 - 5 } & $\left(\mathrm{m}^{3}\right)$ & $\left(\mathrm{g} \mathrm{kg}^{-1}\right)$ & $\mathrm{H}_{2} \mathrm{O}$ & $\mathrm{KCl}$ \\
\hline I & 223.0 & $275.5^{\mathrm{b}}$ & $5.10^{\mathrm{a}}$ & $4.93^{\mathrm{a}}$ \\
II & 389.0 & $57.1^{\mathrm{a}^{*}}$ & $5.28^{\mathrm{a}}$ & $5.04^{\mathrm{a}}$ \\
III & 184.5 & $354.2^{\mathrm{c}}$ & $5.32^{\mathrm{a}}$ & $5.21^{\mathrm{a}}$ \\
\hline
\end{tabular}

* Mean values with the same letter are not significantly different $(P<0.05)$

${ }^{\mathrm{a}, \mathrm{b}, \mathrm{c}}$ Mean values within columns with the different letters are significantly different $(P<0.05)$

$T C$ total organic carbon content
Table 2 Changes in the plant community structure of the studied mountain fen with reference to the plant community structure of the mountain fen with natural water conditions

\begin{tabular}{|c|c|c|}
\hline Parameters & $\begin{array}{l}\text { The average value for } \\
\text { the plant community } \\
\text { structure in the } \\
\text { reference "natural" fen } \\
\% \text { (min-max) }\end{array}$ & $\begin{array}{l}\text { The average value for } \\
\text { the plant community } \\
\text { structure in the restored } \\
\text { fen part with landslide } \\
(\%)\end{array}$ \\
\hline The canopy & $78(60-90)$ & 40 \\
\hline The shrubs & $21(0-40)$ & 90 \\
\hline $\begin{array}{l}\text { Covering the ground } \\
\text { cover layer }\end{array}$ & $81(60-100)$ & 70 \\
\hline $\begin{array}{l}\text { Covering the moss } \\
\text { layer }\end{array}$ & $45(20-70)$ & 30 \\
\hline $\begin{array}{l}\text { Nitrophilic species: } \\
\text { Rubus ideus, } \\
\text { Rubus hirtus, } \\
\text { Urtica dioica) }\end{array}$ & $<5(0-37)$ & 50 \\
\hline
\end{tabular}

positively associated with fen compartment within which peatforming processes began.

\section{Discussion}

The long-term environmental changes induced by ancient landslide in the mountain fen properties (process of soil cover restoration, vegetation structure recovery, and soil microarthropod biodiversity) under the Caltho-Alnetum community in the Babiogórski National Park in Outer Flysch Carpathians, Poland, were determined.

Our field observations in Outer Flysch Carpathians corroborate the message implicit from the global literature (e.g., Geertsma and Pojar 2007; Geertsma et al. 2009; Błońska et al. 2016, 2018) that landslides change site-specific soil properties of mountain fen, such as density, structure, porosity, surface texture, and chemistry, and also vegetation structure and soil microarthropod community. By changing sitespecific conditions, landslides influence on the biodiversity and peatland ecosystems functioning (Pop and Chitu 2013; Pánek and Lenart 2016). In our case, the occurrence of the landslide did not cut off water supply enabling the recovery in soil cover and vegetation structure. This increased over time soil saturation which caused that accumulation of organic matter started again and the new organic layer was formed.

During the conducted study, the lowest value of total organic carbon was determined for soils of the second (deluvial) layer in comparison with original (III) and organic (I) layers. According to Blońska et al. (2018) and Nicia et al. (2018a), the organic carbon and organic matter content play a major role in early stage of formation of soil cover and vegetation.

Assuming that the mass movements started around 1850, we may conclude that the organic matter accumulation rate 
Fig. 3 CCA correlation biplot with environmental variables displaying distribution pattern of Collembola in different compartments of the ancient landslide-affected mountain fen. CCA model calculated with $\log (\mathrm{x} 10+1)$ transformed species data. The full names of species are given in Appendix A. Only species whose abundance values are in the range $-100 \%$ are presented

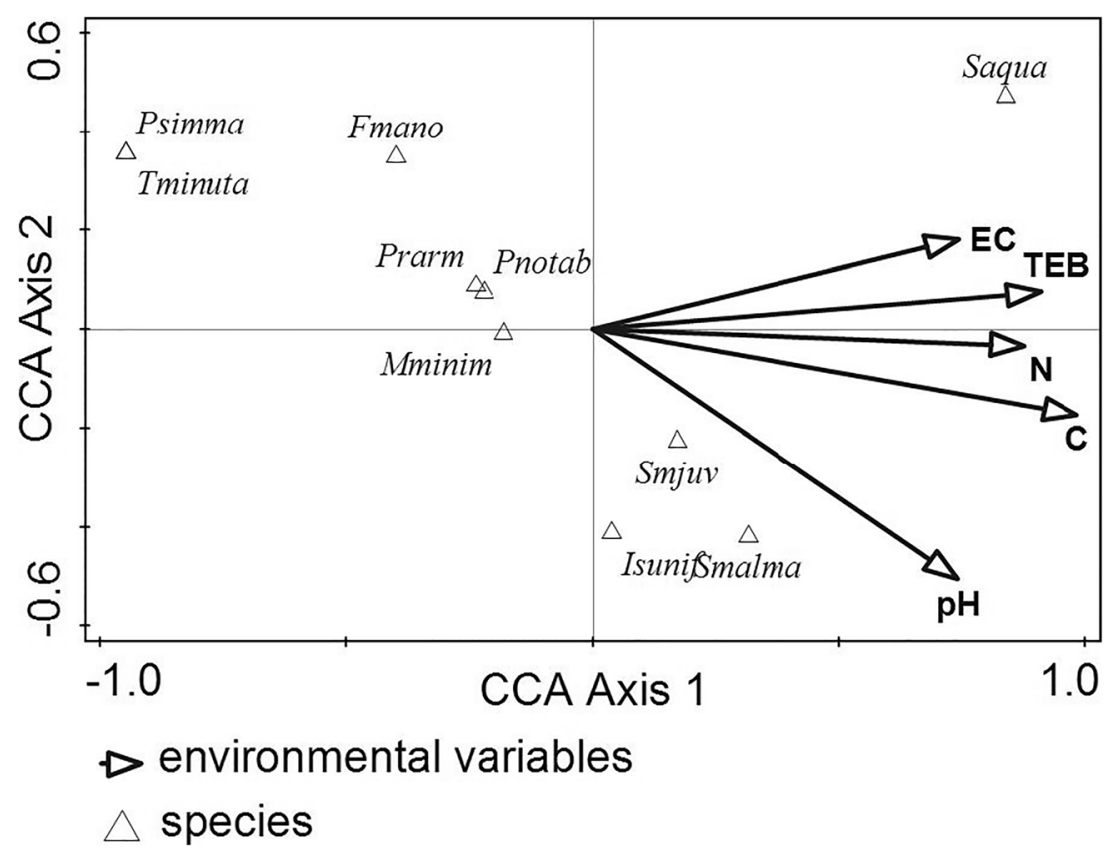

was between 0.9 and $1.2 \mathrm{~mm}$ per year. A similar organic matter accumulation rate was described by Gradziński et al. (2003) in peatlands at the River of Narew and Kalnina et al. (2015) in peatlands in Latvia. It should be mentioned that the organic matter accumulated after the landslide was formed not only by plants present in the habitat. The study showed accumulation of beech tree leaves from a neighboring habitat. Considering the above, we may conclude that the increase in the thickness of the organic soil was due to the accumulation of plants present in the habitat. However, this process has been very slow.

The recorded highest $\mathrm{pH}$ values in the III layer and observed decrease in the others can be explained by the presence of $\mathrm{Ca}$ and $\mathrm{Mg}$ ions in habitat water, since they neutralize acidic organic matter decomposition products. Similar dependencies connected with the influence of mineral soil components on the $\mathrm{pH}$ values of the mountain fen soils were described by Nicia and Bejger (2012) and in the lowland organic soils by Bieniek and Łachacz (2012).
The large changes in the lower layers of vegetation caused by deforestation were observed. Deforestation not only is the result of anthropogenic changes caused by local decline of groundwater level but also is caused by natural factors, for example, climate changes, drought, and pathogens. Increased light penetration creates favorable conditions in dried areas to the appearance and growth of woody species. The expansion of nitrophilous species in the ground cover indicates increased level of nitrogen in soil due to aerobic decomposition of peat (Schrautzer et al. 2013; Glina et al. 2016). Colonizing plants respond to changes in site and soil, generating and maintaining diversity. The diversity of ecosystems is the fundamental basis of the development of many organisms (Geertsma and Pojar 2007; Pop and Chitu 2013).

It was established that restoration of natural hydrologic regime, and increasing level of soil saturation in mountain fen after about 200 years landslide, leads to significant changes in abundance and diversity of soil microarthropod communities represented by Collembola. This result is consistent with van
Table 3 Ancient landslide effect in mountain fen soils on Collembola abundance ( $A$ ind. $\left.\mathrm{m}^{2}\right)$, species richness $(S)$, Shannon diversity index $\left(H^{\prime}\right)$, and Pielou evenness index $\left(J^{\prime}\right)$

\begin{tabular}{|c|c|c|c|c|c|c|}
\hline \multirow[t]{2}{*}{ Collembola } & \multicolumn{2}{|c|}{ Restored area } & \multicolumn{2}{|c|}{ Not-restored area } & \multirow[t]{2}{*}{ Value of $U$ test* } & \multirow[t]{2}{*}{$P$} \\
\hline & Means & $\mathrm{SD}$ & Means & SD & & \\
\hline$A$ & 135.11 & 176.89 & 1183.19 & 3768.97 & 17.00 & $<0.0000$ \\
\hline$S$ & 0.336 & 1.75 & 0.770 & 7.14 . & 7.00 & $<0.0000$ \\
\hline$H^{\prime}$ & 0.095 & 0.59 & 0.047 & 1.32 & 4.50 & $<0.0000$ \\
\hline$J^{\prime}$ & 0.087 & 0.62 & 0.028 & 0.63 & 42.50 & 0.0027 \\
\hline
\end{tabular}

Values are means \pm standard deviation (SD) of five replicates of Collembola community characteristics within restored and not-restored part of fen

*Significant differences of Collembola communities' attributes tested by two-tailed Mann-Whitney $U$ test Italicized values indicate significance level $P$, where statistically significant differences were observed 
Table 4 Results of interactive stepwise (forward) selection procedure in CCA and ranking of examined soil properties in importance by simple and conditional effect on the Collembola communities' variation

\begin{tabular}{|c|c|c|c|c|c|c|c|c|}
\hline \multirow[t]{2}{*}{ Predictor } & \multicolumn{4}{|c|}{ Simple effect } & \multicolumn{4}{|c|}{ Conditional effect } \\
\hline & $\begin{array}{l}\text { Exp- } \\
1 \%\end{array}$ & $\begin{array}{l}\text { pseudo- } \\
F\end{array}$ & $P$ & $\mathrm{p}(\operatorname{adj})$ & Exp-a \% & $\begin{array}{l}\text { pseudo- } \\
F\end{array}$ & $P$ & $\mathrm{p}(\operatorname{adj})$ \\
\hline $\mathrm{TC}$ & 27.5 & 3.0 & 0.002 & 0.010 & 27.5 & 3.0 & 0.002 & 0.010 \\
\hline $\mathrm{TN}$ & 24.2 & 2.6 & 0.018 & 0.072 & 11.8 & 1.4 & 0.194 & 0.752 \\
\hline $\mathrm{pH}$ & 23.9 & 2.5 & 0.018 & 0.072 & 11.6 & 1.4 & 0.188 & 0.752 \\
\hline TEB & 21.2 & 2.2 & 0.018 & 0.072 & 8.6 & 1.1 & 0.314 & 0.752 \\
\hline $\mathrm{EC}$ & 18.5 & 1.8 & 0.052 & 0.072 & 8.5 & 1.1 & 0.42 & 0.752 \\
\hline
\end{tabular}

Exp-1\% simple effect with only one variable, Exp- $a \%$ conditional effect with variable; $p s e u d o-F$ value of the $F$ statistic; $P$ significance level tested by partial Monte Carlo permutation test under reduced model with 499 permutations; $p$ (adj) with Bonferroni correction; $T C$ total organic carbon content; $T N$ total nitrogen content; $T E B$ total exchangeable base; $E C$ electrical conductivity

Italicized values indicate significance level $P$, where statistically significant differences were observed
Dijk et al. (2009) observation that reducing decomposition and mineralization of organic matter by increasing groundwater level could lead to differences in soil fauna communities and confirm the sensitivity of soil microarthropods to environmental changes in mountain fens. Hydrophilic species, such as Sminthurinus aquaticus and S. malmgreni in Collembola community, restored part of the fen, can be considered a strong ecological filter for the soil biota.

The CCA analysis with interactive stepwise (forward) selection of environmental variables, which indicated that total carbon content in soil was the best predictor of the Collembola community variation, allows us to point out that the postdisturbance heterogeneity in the soil organic matter pool through providing new microhabitats can have a long-term influence on the soil biota distribution pattern. The identified effect of landslide on soil carbon stock and biogeochemical properties in forest soil is consistent with Blońska et al. (2018) and Cheng et al. (2016) results. The observed changes in the biodiversity and abundance in soil microarthropod communities confirm that landslides play an important role in the maintenance of biodiversity (Geertsma et al. 2009). The reported higher Collembola abundance and diversity in its mineral part are compatible with the research carried out regarding the response of other soil microarthropod taxa, such as Oribatidmite community in a monsoon forest disturbed by a landslide (Chien et al. 2017). Differences in Collembola abundance and diversity between restored and not-restored part of the fen can also be related to changes in the process of litter decomposition, mainly through their inhibition or stimulation effect on soil microorganisms (Hättenschiler et al. 2005).

\section{Conclusions}

Our results clearly demonstrate that the landslide itself initiated a complex and lengthy process of changes in biological aspects of peatlands including the biodiversity of the underground fauna and plant community. During the study, we noted that over 200 years natural regeneration processes related to changes in the structure of the soil profile in its central part, through re-formation of a saturated soil organic layer formed on the landslide layer and initiation of the peat-forming process, caused drastic decline in abundance and diversity of soil microarthropod communities represented by Collembola. Soil microarthropod communities represented by Collembola can be used as a good indicator of mountain fen regeneration process.

Funding information This research was supported by the National Centre of Science (NCS), Poland, Projects Nos., N N305 107540, N N304 156240, and N N305 396838.

Open Access This article is distributed under the terms of the Creative Commons Attribution 4.0 International License (http:// creativecommons.org/licenses/by/4.0/), which permits unrestricted use, distribution, and reproduction in any medium, provided you give appropriate credit to the original author(s) and the source, provide a link to the Creative Commons license, and indicate if changes were made.

\section{References}

Alexandrowicz Z, Margielewski W (2010) Impact of mass movements on geo- and biodiversity in the polish outer (flysch) Carpathians. Geomorphology 123(3-4):290-304

Bieniek A, Łachacz A (2012) Transformations of peat soil exposed to drainage in Łysa River Vallery. In: Szajdak LW, Gaca W, Meysner T, Styła K, Szczepański M (eds) Necessity of peatland protection. Institute for Agricultural and Forest Environment, Polish Academy of Sciences, Poznań

Błońska E, Lasota J, Zwydak M, Klamerus-Iwan A, Gołąb J (2016) Restoration of forest soil and vegetation 15 years after landslides in a lower zone of mountains in temperate climates. Ecol Eng 97: 503-515

Blońska E, Lasota J, Piszczyk W, Wiecheć M, Klamerus-Iwan A (2018) The effect of landslide on soil organic carbon stock and biochemical properties of soil. J Soils Sediments 18:2727-2737 
Bretfeld G (1999) Synopses on Palearctic Collembola. In: Dunger W (ed) volume 2. Symphypleona. Abh. Ber. Naturkundemus. Görlitz 71:1318

Briones MJI (2014) Soil fauna and soil functions: a jigsaw puzzle. Front Environ Sci 2:7

Brussard L (1997) Biodiversity and ecosystem functioning in soil. Ambio 26:563-570

Celiński F, Wojterski T (1978) Forest communities in Babia Góra. PTPN, Wydz Mat-Przyr. Prace Kom Biol 48:1-62 (in Polish)

Charman D (2002) Peatlands and environmental change. Wiley, West Sussex

Cheng C-H, Hsiao S-C, Hunag Y-S, Hung C-Y, Pai C-W, Chen C-P, Menyailo OV (2016) Landslide -induced changes of soil physical and chemical properties in Xitou, Central Taiwan. Geoderma 265: 187-195

Chien H-C, Hou P-CL, Wasserstrom H, Steinerger Y (2017) Landslide effect on an Oribatid-mite community in a monsoon forest. Adv Environ Res 1:20-28

Council Directive 92/43/EEC (1992) 21 May 1992 on the conservation of natural habitats and of wild fauna and flora

Dojlido J (1999) Physicochemical examination of water and wastewater. Arkady Publishers, Warsaw (in Polish)

Dunger W, Schlitt B (2011) Synopses on Palaearctic Collembola: Tullbergiidae. Soil Org 83:1-168

Fjellberg A (1998) The Collembola of Fennoscandia and Denmark. Part I: Poduromorpha. Fauna Entomol Scand 35:1-183

Fjellberg A (2007) The Collembola of Fennoscandia and Denmark. Part II: Entomobryomorpha and Symphypleona. Fauna Entomol Scand 42:1-264

García-Ruiz JM, José M, Beguería S, Arnáez J, Sanjuán Y, Lana-Renault N, Gómez-Villar A, Álvarez-Martínez J, Coba-Pérez P (2017) Deforestation induces shallow landsliding in the montane and subalpine belts of the Urbión Mountains, Iberian Range, Northern Spain. Geomorphology 296:31-44

Geertsma M, Pojar JJ (2007) Influence of landslides on biophysical diversity - a perspective from British Columbia. Geomorphology 89(1):55-69

Geertsma M, Highland L, Vaugeouis L (2009) Environmental impact of landslides. In: Sassa K, Canuti P (eds) Landslides - diaster risk reduction. Springer-Verlag, Berlin

Glina B, Bogacz A, Gulyás M, Zawieja B, Gajewski P, Kaczmarek Z (2016) The effect of long-term forestry drainage on the current state of peatland soils: a case study from the Central Sudetes, SW Poland. Mires Peat 18(21):1-11

Gnatowski T, Szatyłowicz J, Brandyk T, Kechavarzi C (2010) Hydraulic properties of fen peat soils in Poland. Geoderma 154:88-195

Gradziński R, Baryła J, Doktor M, Gmur D, Gradziński M, Kędzior A, Paszkowski M, Soja M, Zieliński T, Żurek S (2003) In-channel accretionary macroforms in the modern anastomosing system of the upper Narew river NE Poland. Ann Soc Geol Pol 73:35-53

Harrison PA, Vandewalle M, Sykes MT, Berry PM, Bugter R, de Bello F, Feld CK, Grandin U, Harrington R, Haslett JR, Jongamn RHG, Luck GW, da Silva PM, Moora M, Settelle J, Sousa JP, Zubel M (2010) Identifying and prioritising services in European terrestrial and freshwater ecosystems. Biodivers Conserv 19:2791-2821

Hättenschiler S, Tiunov AV, Scheu S (2005) Biodiversity and litter decomposition in terrestrial ecosystems. Annu Rev Ecol Evol Syst 36: $191-218$

Jordana R (2012) Synopses on Palaearctic Collembola - Capbryinae and Entomobryini. Soil Org 84:1-391

Kalnina L, Stivrins N, Kuske E, Ozola I, Pujate A, Zeimule S, Grudzinska I, Ratniece V (2015) Peat stratigraphy and changes in peat formation during the Holocene in Latria. Quat Int 383:186-195
Kogut JP, Pilecka E, Szwarkowski D (2018) Analysis of landslide effects along a road located in the Carpathian flysch. Open Geosci 10:517531

Lacasse S, Nadim F (2009) Landslide risk assessment and mitigation strategy. In: Sassa K, Canuti P (eds) Landslides - disaster risk reduction. Springer, Berlin

LECO (1996) CNS-2000 elemental analyzer-instruction manual. LECO Corp, St. Joseph

Leps J, Smilauer P (2003) Multivariate analysis of ecological data using CANOCO. Cambridge University Press, Cambridge. https://doi. org/10.1017/CBO9780511615146

Macfadyen A (1961) Improved funnel-type extractors for soil arthropods. J Anim Ecol 30:171-184

Magurran AE (2004) Measuring biological diversity. Blackwell Publishing, Malden, USA

Menta C (2012) Soil fauna diversity - function, soil degradation, biological indices, soil restoration. In: Lameed GA (ed) Biodiversity conservation and utilization in a diverse world. InTech, New York

Nakadai Y (2006) Subsistence strategies in mountain settlements - complex use of natural resources in Okutama, Japan and Polish Carpathians. Department of Geography, Graduate School of Science, Tokyo Metropolitan University, Manuscript PhD Thesis

Nicia P (2009) Characteristics and problems of mountain and submontane fens protection. In: Łachacz A (ed) Contemporary problems of management and environmental protection. Wetlands - their functions and protection. Department of Land Reclamation and Environmental Management, University of Warmia and Mazury, Olsztyn

Nicia P, Bejger R (2012) Characteristics and problems of protection of mountain fen soils with diversified type of hydrogenic feeding. In: Szajdak LW, Gaca W, Meysner T, Styła K, Szczepan’ski M (eds) Necessity of peatland protection. Institute for Agricultural and Forest Environment, Polish Academy of Sciences, Poznań

Nicia P, Bejger R, Zadrożny P, Sterzyńska M (2018a) The impact of restoration processes on the selected soil properties and organic matter transformation of mountain fens under Caltho-Alnetum community in the Babiogórski National Park in Outer Flysch Carpathians, Poland. J Soils Sediments 18(8):2770-2776

Nicia P, Bejger R, Sterzyńska M, Zadrożny P, Lamorski T, Stary J, Parzych P (2018b) Restoration of hydro-ecological conditions in Carpathian forested mountain fens. Wetl Ecol Manag 26(4):537546

Pánek T, Lenart J (2016) Landslide landscape of the Moravskoslezské Beskydy Mountains and their surroundings. In: Pánek T, Hradecký J (eds) Landscapes and landforms of the Czech Republic. World Geomorphological Landscapes. Springer, Cham

Pomorski RJ (1998) Onychiurinae of Poland (Collembola: Onychiuridae). Genus, Wroclaw

Pop DA, Chitu Z (2013) Landslides and biodiversity conservation: the importance of an integrated approach. A case study: the subcarpathian part of the Doftana watershed (Prahova County, Romania). Revista de Geomorfologie 15:57-68

Poprawa D, Ryczkowski W (2003) Carpathian landslides (southern Poland). Prz Geol 51:685-692

Potapov M (2001) Synopses on Palaearctic Collembola. Isotomidae. Abh. Ber. Naturkundemus Görlitz 73:1-603

Reinhardt-Imjela C, Jens B, Bölscher J, Schulte A (2018) The impact of late medieval deforestation and 20th century forest decline on extreme flood magnitudes in the Ore Mountains (Southeast Germany). Quat Int 475:42-53

Rusek J (1998) Biodiversity of Collembola and their functional role in the ecosystem. Biodivers Conserv 7:1207-1219 
Schrautzer J, Sival F, Breuer M, Runhaar H, Fichtner A (2013) Characterizing and evaluating successional pathways of fen degradation and restoration. Ecol Indic 25:108-120

Sterzyńska M, Shrubovych J, Kaprus I (2014) Effect of hydrologic regime and forest age on Collembola in riparian forests. Appl Soil Ecol 75:199-209

Sterzyńska M, Tajovsky K, Nicia P (2015) Contrasting responses of millipedes and terrestrial isopods to hydrologic regime changes in forested mountain wetlands. Eur J Soil Biol 68:33-41

Tan KH (2005) Soil sampling, preparation and analysis. Taylor \& Francis Group, Boca Raton

Thibaud JM, Schulz HJ, da Gama Assalino MM (2004) Synopses on Palaearctic Collembola. Hypogastruridae. Abh. Ber. Naturkundemus Görlitz 75:1-287
Van Dijk J, Didden WAM, Kuenen F, van Bodegon PM, Verhoeff HA, Aerts R (2009) Can differences in soil community composition after peat meadow restoration lead to different decomposition and mineralization rates? Soil Biol Biochem 41:1717-1725

Xu G-L, Kuster TM, Günthardt-Goerg MS, Dobbertin M, Li M-H (2012) Seasonal exposure to drought and air warming affects soil Collembola and mites. PLoS One 7:e43102. https://doi.org/10. 1371/journal.Pone.0043102

Publisher's note Springer Nature remains neutral with regard to jurisdictional claims in published maps and institutional affiliations. 